\title{
Chemical Control of Asian Soybean Rust and Its Effect in the Yield and Quality of Soybean Seeds
}

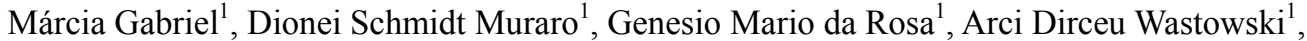 \\ Stela Maris Kulczynski ${ }^{1}$, Juliano de Cesar da Silva ${ }^{1}$, Ivan Ricardo Carvalho ${ }^{2}$, Vinícius Jardel Szareski ${ }^{2}$, \\ Vanessa Alba da Silva ${ }^{1} \&$ Juliano de Oliveira Stumm ${ }^{1}$ \\ ${ }^{1}$ Federal University of Santa Maria, RS, Brazil \\ ${ }^{2}$ Federal University of Pelotas, Campus Capão do Leão, RS, Brazil \\ Correspondence: Ivan Ricardo Carvalho, Universidade Federal de Pelotas, Campus Capão do Leão, CEP \\ 96050-500, Capão do Leão, RS, Brazil. E-mail: carvalhoirc@gmail.com
}

Received: April 8, $2018 \quad$ Accepted: May 20, $2018 \quad$ Online Published: September 15, 2018

doi:10.5539/jas.v10n10p518 URL: https://doi.org/10.5539/jas.v10n10p518

\begin{abstract}
The objective of this study was to evaluate the effect of a foliar fungicide commonly used to control Asian soybean rust (Phakopsora pachyrhizi) in the physiological and sanitary quality of soybean seeds. The experiment was carried out during the 2012/13 field season, with six treatments and four replications arranged in a randomized complete block design. The following treatments were evaluated: T1 (no fungicide application); one application at R1 stage; two applications at R1 and R3 stages; three applications at R1, R3, and R5 stages; four applications at R1, R3, R5, and R6 stages and five applications at R1, R3, R5, R6 and R7 stages. Seeds yield, seed weight, viability and vigor assessments were used to measure the impact of foliar fungicide applications on soybean yield and seed quality. The results indicated that four fungicide applications provide higher grain yield, increased seed weight, and germination percentages within commercial standards. In contrast, the number of fungicide applications did not correlate with the sanitary quality of the seeds.
\end{abstract}

Keywords: Phakopsora pachyrhizi, production, physiological potential

\section{Introduction}

Soybean (Glycine $\max$ (L.) Merrill) is the most important oleaginous plant cultivated in the world. Due to its great economic and social importance, is grown over a wide geographic area not only in Brazil but also in other countries (Lazzarotto, 2010; Rigo et al., 2018). In Brazil, during the 2017/2018 soybean crop season, it was estimated that 31.9 million hectares were planted, representing a 3.5\% increase in the national area, with an expected production of approximately 107 million tons (CONAB, 2017).

Among the factors that define the success of soybean cultivation is the use of high quality seeds, which will generate high vigor plants that will have a superior performance in the field. Infer that the use of high quality seed allows access to genetic advances, quality assurance and adaptation technologies in the different regions, ensuring greater productivity (França-Neto et al., 2016; Carvalho et al., 2016; Nardino et al., 2016; Ferrari et al., 2016). Therefore, the quality of seeds is of great importance, since it affects both the return of the invested capital and the yield potential for the next crop season (Szareski et al., 2016; Strobel et al., 2016).

Along with the expansion of the production area over the years, an increase in diseases caused by fungi, bacteria, viruses, and nematodes has been observed. This is the case of Asian Soybean Rust (ASR), a disease caused by the fungal pathogen Phakopsora pachyrhizi that causes rapid leaf yellowing, premature senescence, and impairs root formation (Soares et al., 2004). ASR is considered one of the most detrimental factors that affects soybean production nowadays.

In this context, due to the limited availability of ASR-resistant soybean cultivars, the foliar application of fungicides to target this disease has been the most important tool used by farmers to provide greater sanity to the plants, thus ensuring maximum yield potential and seeds quality for this oilseed (Godoy et al., 2007).

Being a polycyclic disease and thus present in the field practically throughout the plant cycle (Godoy et al., 2004), an efficient ASR control usually requires a number of fungicide applications with short application intervals. On favorable epidemic conditions, three to five applications are necessary at ten-day intervals (Sinclair and Hartman, 
1995), spanning both the vegetative and the reproductive stages. This may be concerning since it could lead to fungicide residue in the plant tissues, most importantly in the seeds, after harvesting (Vargas et al., 2018).

Therefore, the objective of this work was to gain knowledge on the impact of the number of foliar fungicide applications in the yield, physiological, and sanitary quality of soybean seeds.

\section{Material and Methods}

To assess the impact of the number of fungicide applications for the control of Asian rust (Phakopsora pachyrhizi), residue level and seed quality of soybean, an experiment was carried out in the Federal University of Santa Maria, Campus FredericoWestphalen, Rio Grande do Sul, Brazil, using a mixture of strobilurin + triazol (109.8 g.ai/ha) for all applications.

The soil of the area is classified as a clayey dystrophic red latosol (Embrapa, 2006). The location of the experimental area is defined by the geographical coordinates latitude $27^{\circ} 25^{\prime} 43^{\prime \prime} \mathrm{S}$, longitude $53^{\circ} 43^{\prime} 25^{\prime \prime} \mathrm{W}$ and average altitude of $488 \mathrm{~m}$. According to the classification of Köeppen the climate of the region is subtropical humid, with average annual rainfall of $2100 \mathrm{~mm}$.

The experimental design was randomized complete block, with four replications. The treatments were: untreated check; one application; R1 growth stage; two applications; R1 and R3; three applications; R1, R3, and R5; four applications; R1, R3, R5, and R6; five applications; R1, R3, R5, R6, and R7.The local daily precipitation data and the minimum and maximum temperatures were collected using an automatic local weather station (Figure 1).

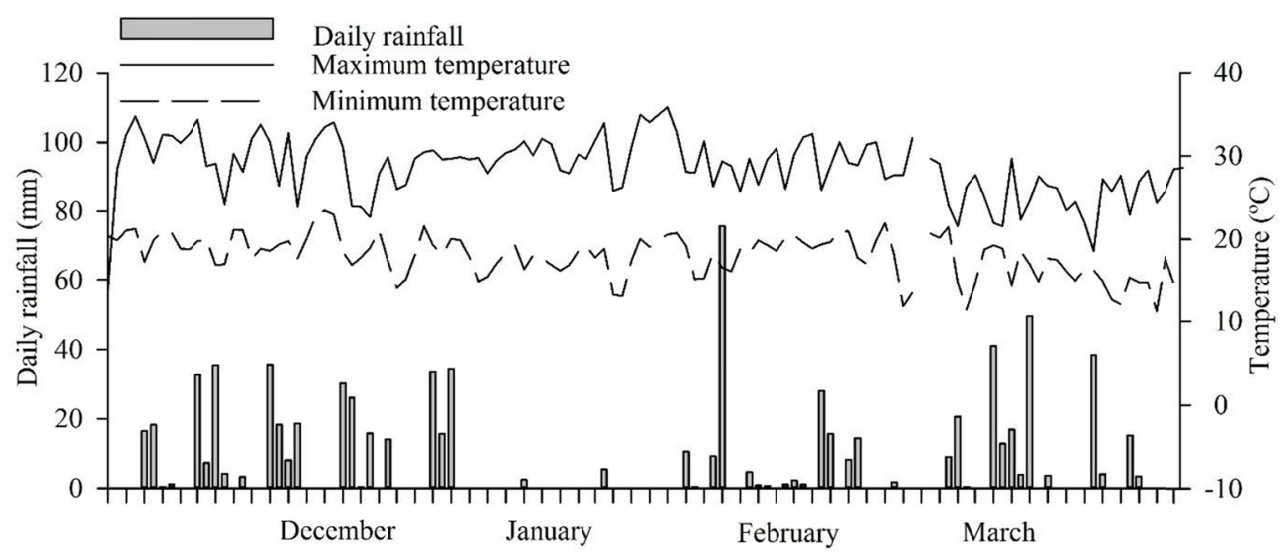

Figure 1. Daily average temperatures and rainfall during the conduction of the experiment. The rainfall data were obtained from the Meteorological Station of FredericoWestphalen-RS

Soybean fertilization was carried out according to the recommended values (CQFS, 2004) for soybean crop in no-tillage, having as parameter the grain yield of $4200 \mathrm{~kg} \mathrm{ha}^{-1}$, and based on the soil chemical analysis. The soil physical and chemical characteristics were the following: $42 \%$ clay, $\mathrm{pH} 6.2$ in water, SMP index 6.4, Phosphorus (P) $9.2 \mathrm{mg} \mathrm{L}^{-1}$, potassium (K) $198.5 \mathrm{mg} \mathrm{L}^{-1}, 10.3 \mathrm{cmol}_{\mathrm{c}} \mathrm{L}_{\text {calcium }}{ }^{-1}$, magnesium $4.2 \mathrm{cmol}_{\mathrm{c}} \mathrm{L}^{-1}$, organic matter (MO) $3.4 \%$.

Sowing of soybean seeds was performed manually, on 12/02/2012, using seeds previously treated with fungicide and inoculant. Each plot consisted of 12 rows of soybean $(0.45 \mathrm{~m}$ spacing) by $2.5 \mathrm{~m}$ length, considering as a sampling area the 6 central rows, excluding $0.75 \mathrm{~m}$ from each end.

Harvesting was done manually on $03 / 30 / 2013$ and the yield estimated in $\mathrm{kg} \mathrm{ha}^{-1}$ corrected to $13 \%$ moisture. Subsequently, the seeds were packed in paper containers and kept in a dry place with relative air humidity around $40 \%$. From each plot a sample was taken for physiological and sanitary analysis. For the parameter thousand-seed weight (TSW) the degree of humidity (U) was determined with a Digital Moisture Meter MOD. 919 FOB, by counting and weighing 8 subsamples of 100 seeds from each plot using a precision scale (Brazil, 2009).

Yield was determined based on the final population of existing plants in the sampling area $\left(2.7 \mathrm{~m}^{2}\right)$ of each plot. Seeds yield of each replicate was calculated and the value obtained $\left(\mathrm{kg} \mathrm{parcela}^{-1}\right)$ was transformed to yield $(\mathrm{kg}$ $\left.\mathrm{ha}^{-1}\right)$. 


\subsection{Seed Physiological Quality Assessment}

For physiological quality assessment, seed samples were submitted to germination and vigor tests (Brazil, 2009). The vigor tests evaluated were: physiological tests (first germination count, seedling length, and seedling fresh and dry weight; resistance test (accelerated aging) and biochemical test (electrical conductivity) as described below.

Germination test (GT): The test consisted of four replicates of 100 seeds per treatment, distributed on a roll of three wet sheets of germination paper followed by incubation in a germinator regulated with a constant temperature of $25 \pm 2{ }^{\circ} \mathrm{C}$, with a 12 hour photoperiod. Five days after incubation, samples were taken for determination of vigor and on the eighth day for determination of germination percentage, according to the criteria established by the Rules for Seed Analysis (Brazil, 2009).

First counting (FC): performed with the twinning test after the fifth day of the test. Results expressed as percentage of normal seedlings. Normal seedlings were those with well-formed root system and perfect coleoptile, well-developed leaf (plumule) inside or emerged from it. Abnormal seedlings had poorly formed and necrotic roots, empty coleoptile, primordial leaves split or longitudinally split, and abnormal or absent hypocotyl development (Brazil, 2009).

Length of seedlings (LS): Seedling length was evaluated eight days after germination through measurement of shoot length (SL), root length (RL), and total length (TL), the latter obtained by the sum of the two previous variables. For this analyzes, four replicates of 10 normal seedlings randomly chosen were used.

Dry seedling mass (DSM): The test was carried out with normal seedlings obtained from the germination test, including all parts of the seedlings; Radicle, hypocotyl, cotyledons and primary leaves. Four replicates of 10 seedlings per treatment were placed in paper containers and dried at $70{ }^{\circ} \mathrm{C}$. Containers were weighted until reaching constant weight (Santos, 2009). Data were expressed as milligrams (mg).

Accelerated aging (EA): The test was conducted using 400 seeds per treatment, two samples of 100 seeds distributed in a single layer on a steel screen and placed in plastic gerbox boxes containing $40 \mathrm{ml}$ of distilled water, with a distance between the water level and the seeds of approximately $2 \mathrm{~cm}$. The boxes were closed and incubated in a germination chamber, regulated at $41{ }^{\circ} \mathrm{C}$ for 48 hours (MarcosFilho et al., 2001). After this period the germination test was carried out as described above.

Electrical Conductivity (EC): The test was conducted with four replicates of 25 seeds per treatment. After weighing each sample, the seeds were placed in plastic cups containing $75 \mathrm{ml}$ of deionized water and kept at $25 \pm 2{ }^{\circ} \mathrm{C}$, with a photoperiod of 12 hours, for 24 hours. Conductivity of the solution was determined by the use of a conductivity meter. Values were divided by the weight of the sample ( $\mathrm{g}$ ) and the results expressed in $\mu \mathrm{S} \mathrm{g}^{-1} \mathrm{~cm}^{-1}$ of seed (MarcosFilho, 2005).

\subsection{Sanitary Quality of Seeds}

The evaluation of the sanitary quality of soybean seeds was performed by the Blotter-test. For this, five replicates of 20 seeds packed in gerbox boxes containing three germination paper sheets moistened with a $\mathrm{KCl}$ solution at 0,9 MPa were used. Samples were incubated for seven days at $25{ }^{\circ} \mathrm{C}$ under a 12 hour photoperiod. Seeds were individually examined and the fungi identified with the aid of a microscope stereoscope, the result being expressed as percentage of contaminated seeds and fungi incidence.

The experimental design used was completely randomized, and the $\mathrm{F}$ test was used, and the means comparison was performed by the Tukey test at the 5\% probability level. The data obtained were analyzed separately for each test.

\section{Results and Discussion}

The analyzed data indicated that only some of the evaluated variables were significantly influenced by the treatments adopted.

According to the data presented in Table 1, the lower yield was observed in without application, which presented statistical difference with the other treatments. The data obtained in this variable are consistent with those found by Brzezinskide et al. (2012), Olsen (2012), and Barros et al. (2008), who observed higher yield of soybean where there were more applications of fungicides to control rust. 
Table 1. Mean values of yield $\left(\mathrm{kg} \mathrm{ha}^{-1}\right)$, weight of thousand seeds, germination and vigor (first count) of soybean plants, according to the number of fungicide applications

\begin{tabular}{lllll}
\hline Treatments & Yield $\left(\mathrm{kg} \mathrm{ha}^{-1}\right)$ & WTS $(\mathrm{g})$ & GT $(\%)$ & FC $(\%)$ \\
\hline Without application & $3169.7 \mathrm{~d}$ & $163.7 \mathrm{~d}$ & $71.00 \mathrm{a}$ & $100.00 \mathrm{a}$ \\
An application & $3765.5 \mathrm{c}$ & $168.7 \mathrm{dc}$ & $78.00 \mathrm{a}$ & $99.66 \mathrm{a}$ \\
Two applications & $4376.1 \mathrm{~b}$ & $177.2 \mathrm{bc}$ & $76.32 \mathrm{a}$ & $100.00 \mathrm{a}$ \\
Three applications & $4865.8 \mathrm{a}$ & $184.7 \mathrm{ab}$ & $74.16 \mathrm{a}$ & $99.50 \mathrm{a}$ \\
Four applications & $4928.2 \mathrm{a}$ & $188.8 \mathrm{a}$ & $80.66 \mathrm{a}$ & $99.95 \mathrm{a}$ \\
Five applications & $4706.1 \mathrm{ab}$ & $187.8 \mathrm{a}$ & $71.00 \mathrm{a}$ & $99.82 \mathrm{a}$ \\
\hline C.V. $(\%)$ & 3.65 & 4.03 & 11.97 & 0.53 \\
\hline
\end{tabular}

Note. WTS: weight of thousand seeds; GT: germination; FC: first count; Means followed by the same letter in each column do not differ from each other by the Tukey test at the 5\% probability level.

The increase in yield (Table 1), relative to the control, ranged from $595.8 \mathrm{~kg} \mathrm{ha}^{-1}$ to $1758.5 \mathrm{~kg} \mathrm{ha}^{-1}$ for two applications and four applications. The lack of fungicide application in the untreated plot reduced yield by $35.6 \%$ the production when compared to the higher production four applications, with four applications. Soybean plants severely infected with this disease present early defoliation, which compromises the formation and filling of pods and the final weight of the grains (Yorinori \& Lazzarotto, 2004; Szareski et al., 2018).

The preventive and sequential application of the fungicide was essential for increasing yield, as it can be seen in Table 1. This is because preventive applied fungicides have been highlighted as the most effective strategy in controlling diseases, avoiding the early defoliation that leads to the loss of photosynthetic area of the plant that consequently reduces the filling of the seeds and reducing productivity (Finoto et al., 2011; Meier et al., 2016).

The highest yield was obtained when three or four applications were performed. These results corroborate with the data presented by Barros et al. (2008), which obtained higher yield when working with three fungicide applications in the control of Asian rust in the soybean crop. In studies by Sinclair and Hartman (1995), the authors observed that in severe epidemic conditions, three to five applications are required at 10-day intervals. A fact also highlighted by Levy (2005) who stated that three or more applications are necessary to maintain productive potential. The reduction of the range of fungicide applications is in function of the intensity of the disease and this is related to the climatic conditions throughout the cycle of the culture (Godoy et al., 2009). In this sense (Figure 1), the climate conditions during the development of the experiment were favorable, with rains within the average, relative humidity of about $80 \%$ and maximum and minimum temperatures around 20 to $25^{\circ} \mathrm{C}$. Precipitation has a direct effect on the epidemic because it is related to the dispersion of spores within the canopy, contributing to the rapid development of the disease (Tchanz, 1982). The temperature and humidity favor the germination of the fungus (Sinclair \& Beckman, 1989), who needs free water or dew and favorable temperature between 20 and $25{ }^{\circ} \mathrm{C}$

For the PMS parameter (Table 1), the control treatment had the lowest value, resulting in a reduction of $13.29 \%$ in comparison with four applications, with four applications, but only an application did not differ statistically from the control. Results corroborate with those obtained by Nunes et al. (2012) observed that the weight of the seeds of the treatments that received an application presented no difference of those that received, two application of fungicide. These results indicate that there was a relationship between the different fungicide applications, due to the damage caused by the disease (Figure 2), resulting in a lower seed mobilization capacity, which resulted in reduction of the mass and, consequently, of the final productivity. The loss of leaf area caused by the disease affects the interception of light, the photosynthetic capacity and the accumulation of photosynthates in the period of grain filling (Board et al. 1994),

Also in relation to the weight of thousand seeds (WTS), the increase in relation to the control ranged from $5 \mathrm{~g}$ to $25.1 \mathrm{~g}$, for an application treatments with an application in R1 (beginning of flowering) and Four applications with four applications in (beginning of flowering, beginning the formation of the pod, initiation of the grain filling and full grain) R1, R3, R5 and R6, respectively.

Although the weight of the without application seeds was statistically lower than the other treatments, this did not affect the germination and vigor (first count; Table 1) these parameters did not present statistical difference for the germination parameter, the seeds of the treatments. With greater weight presented, numerically, greater percentage of germination. This fact may be related to the maintenance of the leaf area for longer, depending on the application of the fungicide (Teló et al., 2011; Follmann et al., 2017). According to Pereira et al. (2009), plants that 
receive the application of fungicides that have strobilurins in their composition may present a longer period of photosysetically active foliage, since the strobilurins act in the activation of NADH-nitrate reductase enzyme, increasing nitrate assimilation and its Subsequent incorporation into the plant's vital molecules, such as chlorophyll.

For the germination test, only four applications presented average acceptable percentages established for the commercialization of soybean seeds, that is, minimum standard of $80 \%$ of germination (MAPA, 2009). However, these results differ from those of Gagliardi et al. (2009), Pinto et al. (2011) and Brzezinskide et al. (2012), which verified that the leaf fugicides applied to the rust control did not affect the physiological quality of the seeds produced, presenting germinative power above $80 \%$.

Analyzing the physiological tests of vigor (Table 2), it was observed that there was no statistical difference between treatments in the parameters of shoot length, root length and dry mass weight. According to Nakagawa (1999), these tests are considered less sensitive to detect differences in vigor when compared to other vigor tests.

Table 2. Mean values of the physiological tests of vigor of soybean seeds, as a function of the number of foliar fungicide application

\begin{tabular}{|c|c|c|c|}
\hline \multirow{2}{*}{ Treatments } & \multicolumn{2}{|c|}{ Length of seedlings $(\mathrm{mm})$} & \multirow{2}{*}{$\begin{array}{l}\text { Wheight of Seedlings }(\mathrm{g}) \\
\text { MSP }\end{array}$} \\
\hline & $\mathrm{CPA}$ & $\mathrm{CR}$ & \\
\hline Without application & $115.74 \mathrm{a}$ & $104.81 \mathrm{a}$ & $1.22 \mathrm{a}$ \\
\hline An application & $116.29 \mathrm{a}$ & $104.54 \mathrm{a}$ & $1.25 \mathrm{a}$ \\
\hline Two applications & $117.42 \mathrm{a}$ & $105.11 \mathrm{a}$ & $1.25 \mathrm{a}$ \\
\hline Three applications & $117.16 \mathrm{a}$ & $105.86 \mathrm{a}$ & $1.27 \mathrm{a}$ \\
\hline Four applications & $118.94 \mathrm{a}$ & $105, .67 \mathrm{a}$ & $1.29 \mathrm{a}$ \\
\hline Five applications & $122.77 \mathrm{a}$ & $107.27 \mathrm{a}$ & $1.29 \mathrm{a}$ \\
\hline C.V. $(\%)$ & 10.75 & 5.95 & 4.67 \\
\hline
\end{tabular}

Note. CPA: Aerial part length; CR: root length; MSP: Dry mass of seedlings. Means followed by the same letter in each column do not differ from each other by the Tukey test at the 5\% probability level.

The accelerated aging test did not indicate influence of the different fungicide applications (Table 3). However, the values of the electrical conductivity test presented in the same table, infer that without application, an application and two applications treatments that do not differ statistically from each other, present statistical difference in relation to treatments three applications, four applications and five applications.Through the electrical conductivity data (Table 3) correlated with PMS and germination (Table 1), it can be inferred that the seeds that received the highest number of fungicide application had higher quality. This is justified by the fact that the increase of leachate solutes is directly related to the decrease in seed germination and vigor (Binotti et al., 2008; Aisenberg et al., 2018). Similar results were found by Pinto et al. (2011), who did not observe a difference between the treatments for the accelerated aging test, and also found that seeds that did not receive fungicide application for the control of Asian rust obtained higher leaching of solutes, being considered of lower physiological quality.

Table 3. Average values of vigor based on the resistance and biochemical test of soybean seeds, according to the number of fungicide application via leaf

\begin{tabular}{lll}
\hline \multirow{2}{*}{ Treatments } & Resistence test & Biochemical test \\
\cline { 2 - 3 } & EA $(\%)$ & CE $(\mu \mathrm{S} / \mathrm{cm} / \mathrm{g})$ \\
\hline Without application & $99.00 \mathrm{a}$ & $97.92 \mathrm{a}$ \\
An application & $98.66 \mathrm{a}$ & $91.18 \mathrm{ab}$ \\
Two applications & $98.66 \mathrm{a}$ & $91.12 \mathrm{ab}$ \\
Three applications & $96.00 \mathrm{a}$ & $89.75 \mathrm{bc}$ \\
Four applications & $97.82 \mathrm{a}$ & $85.66 \mathrm{c}$ \\
Five applications & $99.50 \mathrm{a}$ & $87.20 \mathrm{bc}$ \\
\hline C.V. $(\%)$ & 2.59 & 11.32 \\
\hline
\end{tabular}

Note. EA: Accelerated aging; EC: Electrical conductivity. Means followed by the same letter in each column do not differ from each other by the Tukey test at the 5\% probability level. 
The results of fungus incidence in seeds obtained in function of the use of different numbers of fungicide application for the control of Asian rust in the soybean crop are presented in Table 4.

Table 4. Mean percentage data of fungi incidence in soybean seeds, according to the number of fungicide application via leaf

\begin{tabular}{lllllll}
\hline \multirow{2}{*}{ Treatments } & \multicolumn{5}{c}{ Incidence of Pathogens (\%) } \\
\cline { 2 - 7 } & As. fla. & Clad. & Peni. & Epic. & Fus. & Alter. \\
\hline Without application & 57 & 91 & 5 & 36 & 5 & 14 \\
An application & 49 & 91 & 7 & 13 & 3 & 3 \\
Two applications & 43 & 92 & 4 & 18 & 2 & 2 \\
Three applications & 51 & 33 & 1 & 12 & 5 & 4 \\
Four applications & 54 & 93 & 9 & 21 & 4 & 4 \\
Five applications & 23 & 96 & 4 & 22 & 5 & 6
\end{tabular}

Note. As. fla.: Aspergillusflavus spp.; Clad.: Cladosporium spp.; Peni.: Penicilium spp.; Epic.: Epicoccum spp.; Fus.: Fusarium spp.; Alter.: Alternaria spp.

It was observed that all treatments presented the same genus of fungus, but with numerical differences, showing not to be related to the different numbers of fungicide applications. The main genus detected in the seeds wereAspergillus spp., Penicillium spp. (Storage fungi) Cladosporium spp., Epicoccum spp., Fusarium spp. And Alternaria spp. (Fungi field).Gagliardi et al. (2009) found that the fungicides used in the control of Asian rust do not influence the infection of the seeds by these fungi. Studies have shown that seed contamination by fungi can reduce physiological quality, inhibiting germination in some cases, and are also a source of primary inoculum for the disease in the field causing damage to plants and consequently reduction in grain yield (Lasca et al., 1986).

\section{Conclusion}

Four applications of fungicide provided higher yield, higher seed weight and with percentage of germination within the standards for commercialization. The sanitary quality of the soybean seeds was not influenced by the number of fungicide applications.

\section{References}

Aisenberg, G. R., Koch, F., Pimentel, J. R., Troyjack, C., Dubal, I., Santos, L. A., ... Aumonde, T. Z. (2018). Soybean growth, solar energy conversion and seed vigour affected by different nitrogen $(\mathrm{N})$ doses. Australian Journal Crop Science, 12, 343-349. https://doi.org/10.21475/ajcs.18.12.03.pne619

Barros, H. B., Sediyama, T., Reis, M. S., Cecon, P. R. (2008). Efeito do número de aplicações de fungicidas no controle da ferrugem asiática da soja. Acta Scientiarum Agronomy, 30(2), 239-245. https://doi.org/10.4025/ actasciagron.v30i 2.1741

Binotti, F. F. S., Haga, K. I., Cardoso, E. D., Alves, C. Z., \& Sá, M. E. O. (2008). Efeito do período de envelhecimento acelerado no teste de condutividade elétrica e na qualidade fisiológica de sementes de feijão. Acta Scientiarum Agronomy, 30(2), 247-254. https://doi.org/10.4025/actasciagron.v30i2.1736

Board, J. E., Wier, A. T., \& Boethel, D. J. (1994). Soybean yield reductions caused by defoliation during mid to late seed filling. Agronomy Journal, 86, 074-1079. https://doi.org/10.2134/agronj1994.00021962008600 $060027 \mathrm{x}$

Brzezinskide, C. R., Abati, J., Henning, F. A., Neto, J. B. F de, \& Henning, A. A. (2012). Eficiência de fungicidas para controle da ferrugem asiática da soja e sua influência na produtividade e na qualidade de sementes. Informativo ABRATES, 22(3), 84-87.

Carvalho, I. R., Nardino, M., Pelegrin, A. J., Ferrari, M., Demari, G., Szareski, V. J., ... Souza, V. Q. (2016). Path analysis and Annicchiarico method applied in relation to protein in corn grains. Australian Journal of Basic and Applied Sciences, 10, 300-306.

Comissão de Química e Fertilidade do Solo (CQFS RS/SC). (2004). Manual de adubação e calagem para os estados do Rio Grande do Sul e Santa Catarina (10th ed., p. 400). Porto Alegre: Sociedade Brasileira de Ciência do Solo/Núcleo Regional Sul.

CONAB (Companhia Nacional de Abastecimento). (2017). Levantamento de Safras. Brasília: CONAB. Retrieved 
from http://www.conab.gov.br

EMBRAPA (Empresa Brasileira De Pesquisa Agropecuária). (2006). Sistema Brasileiro de Classificação de Solos (2nd ed., p. 412). Brasília, EMBRAPA Produção de informação, Rio de Janeiro, EMBRAPA Solos.

Ferrari, M., Pelegrin, A. J., Nardino, M., Carvalho, I. R., Szareski, V. J., Olivoto, T., ... Souza, V. Q. (2016). Evaluationofsoybeansgenotypes in fieldenvironmentsof Rio Grande do Sul state, Brazil. International Journal of Current Research, 8, 38383-38392.

Finoto, E. L., Carrega, W. C., Sediyama, T., Albuquerque, J. A. A. de, Cecon, P. R., \& Reis, M. S. (2011). Efeito da aplicação de fungicida sobre caracteres agronômicos e severidade das doenças de final de ciclo na cultura da soja. Revista Agro ambiente On-line, 5(1), 44-49. https://doi.org/10.18227/ 1982-8470ragro.v5i1.418

Follmann, D. N., Cargnelutti Filho, A., Souza, V. Q., Nardino, M., Carvalho, I. R., Demari, G., ... Szareski, V. J. (2017). Relações lineares entre caracteres de soja safrinha. Revista de Ciências Agrárias, 40, $213-221$. https://doi.org/10.19084/RCA16027

França-Neto, J. de B., Krzyzanowski, F. C., Padua, G. P. D., Costa, N. P. D., \& Henning, A. A. (2007). Tecnologia da produção de semente de soja de alta qualidade. Embrapa Soja, Brazil.

Gagliardi, B., Carvalho, T. C., Pupim, T. L., Gomes Junior, F. G., Timóteo, T. S., Koboris, N. M., ... Mentem, J. O. M. (2009). Efeito de fungicidas para controle da ferrugem asiática na qualidade de sementes de soja. Revista Brasileira de Sementes, 31(4), 120-125. https://doi.org/10.1590/S0101-31222009000400014

Godoy, C. V., \& Canteri, M. G. (2004). Efeitos protetor, curativo e erradicante de fungicidas no controle da ferrugem da soja causada por Phakopsora pachyrhizi, em casa de vegetação. Fitopatologia Brasileira, 29(1). https://doi.org/10.1590/S0100-41582004000100016

Godoy, C. V., Flausino, A. M., Santos, L. C. M., \& Del Ponte, E. M. (2009). Eficiência do controle da ferrugem asiática da soja em função do momento de aplicação sob condições de epidemia em Londrina, PR. Tropical Plant Pathology, 34, 56-61. https://doi.org/10.1590/S1982-56762009000100011

Godoy, C. V., Pimenta, C. B., \& Wruck, D. S. (2007). Eficiência de fungicidas para o controle da ferrugem asiática da soja em Londrina e Tamarana, PR, na safra 2007/08. Resultados sumarizados dos ensaios em rede (Embrapa Soja, Circular Técnica, 42, p. 8). Londrina: Embrapa Soja.

IMMETRO. (2010). Orientação sobre validação de métodos analíticos. DOQ-CGCRE. Retrieved from http://www.inmetro.gov.br/credenciamento/laboratorios/calibEnsaios.asp

Lasca, C. C., Vechiato, M. H., \& Valarini, P. J. (1986). Detecção identificação de fungos em sementes de sorgo (Sorghum sp.) produzidas no Estado de São Paulo. Arquivos do InstitutoBiológico, 53, 47-54.

Lazzarotto, J. J., \& Hirakuri, M. H. (2010). Evolução e perspectivas de desempenho econômico associadas com a produção de soja nos contextos mundial brasileiro (Embrapa Soja, Documento 319, p. 46). Londrina: Embrapa Soja.

Levy, C. (2005). Epidemiology and chemical control of soybean rust in Southern Africa. Plant Disease, 89(2), 669-674. https://doi.org/10.1094/PD-89-0669

MAPA (Ministério da Agricultura, Pecuária e Abastecimento). (2009). Regras para análise de sementes (p. 395). Brasília: MAPA/ACS.

Marcos Filho, J. (2005). Fisiologia de sementes de plantas cultivadas (1st ed.). Piracicaba: FEALQ. https://doi.org/10.1590/S0103-90162001000200029

Marcos Filho, J., Novembre, A. D. C., \& Chamma, H. M. C. P. (2001). Testes de envelhecimento acelerado e de deterioração controlada para avaliação do vigor de sementes de soja. ScientiaAgricola, 58(2), 421-426.

Meier, C., Meira, D., Olivoto, T., Follmann, D. N., Nardino, M., Carvalho, I. R., ... Souza, V. Q. (2016). Morphological traits and yield components of second-crop soybeans in Rio Grande do Sul state, Brazil. Australian Journal of Basic and Applied Sciences, 9, 81-88.

Nakagawa, J. (1999). Testes de vigor baseados no desempenho de plântulas. In F. C. Krzyzanowski, R. D. Vieira, \& J. B. França Neto (Eds.), Vigor de sementes: conceitos e testes (Cap. 2, pp. 1-24). Londrina: Abrates.

Nardino, M., Carvalho, I. R., Demari, G., Pelissari, G., Pelegrin, A. J., Ferrari, M., ... Souza, V. Q. (2016). Components of variance, linear and canonical correlation soybean cultivars. Australian Journal of Basic and Applied Sciences, 10, 202-208. 
Nunes, C. D. M., Martins, J. F. S., Aguila, L. S. H. D., Friedrich, F. F., \& Ramos, R. S. (2012). Eficiência do Número de Aplicações de Fungicidas no Controle da Ferrugem Asiática da Soja, Safra 2011/2012. XXXIX Reunião de pesquisa de soja da região sul-Atas e Resumos, Embrapa Clima Temperado, Pelotas, RS, Brazil.

Olsen, D. (2012). Fungicidas para controle da ferrugem asiática e sua influência na qualidade de sementes de soja (Dissertação, Mestrado em Ciênciae Tecnologia de Sementes, Universidade Federal de Pelotas, Capão do Leão).

Parreira, D. F., Neves, W. S., \& Zambolim, L. (2009). Resistência de fungos a fungicidas inibidores de quinona. Revista Trópica-Ciências Agrárias e Biológicas, 3(2), 24-34.

Pinto, T. L. F., Cicero, S. M., França-Neto, J. B., Dourado Neto, D., \& Forti, V. A. (2011). Fungicidas foliares e a doença ferrugem asiática na produção e na qualidade de sementes de soja. Revista Brasileira de Sementes, 33(4), 680-688. https://doi.org/10.1590/S0101-31222011000400010

Rigo, G. A., Schuch, L. O. B., Vargas, R. L., Barros, W. S., Szareski, V. J., Carvalho, I. R., ... Pedo, T. (2018). Micronutrient Content and Physiological Quality of Soybean Seeds. Journal of Agricultural Science, 10, 223-230. https://doi.org/10.5539/jas.v10n4p223

Santos, V. J. (2009). Qualidade fisiológica de sementes de cenoura e abóbora classificadas por tamanho (Dissertação de Mestrado, Santa Maria, RS, Brasil).

Silva, J. B. da, Lazarini, E., \& Sá, M. E. de. (2010). Comportamento de sementes de cultivares de soja, submetidos a diferentes períodos de envelhecimento acelerado. Bioscience Journal, 26(5), 755-762.

Sinclair, J. B., \& Backman, P. A. (1989). Compendium of soybean diseases (3rd ed., pp. 24-27). St. Paul: The American Phytopathological Society.

Sinclair, J. B., \& Hartman, G. L. (1995). Proceedings of the Soybean Rust Workshop. Urbana, IL: National Soybean Research Laboratory.

Soares, R. M., Rubin, S. A. L., Wielewicki, A. P., \& Ozelame, J. G. (2004). Fungicidas no controle da ferrugem asiática (Phakopsora pachyrhizi) e produtividade da soja. Ciência Rural, 34(4), 122. https://doi.org/10.1590/ S0103-84782004000400045

Strobel, T., Koch, F., Aisenberg, G. R., Szareski, V. J., Carvalho, I. R., Nardino, M., ... Aumonde, T. Z. (2016). Physical and physiological quality of soybean seeds harvested under different trial systems after storage period. Australian Journal of Basic and Applied Sciences, 10, 124-130.

Szareski, V. J., Carvalho, I. R., Demari, G. H., Pelissari, G., Pelegrin, A. J., Barbosa, M. H., ... Aumonde, T. Z. (2018). Path analysis applied to agronomic traits of contrasting growth habit soybeans. Australian Journal Crop Science, 12, 531-538. https://doi.org/10.21475/ajcs.18.12.04.pne608

Szareski, V. J., Carvalho, I. R., Nardino, M., Demari, G., Bahry, C. A., Kehl, K., ... Aumonde, T. Z. (2016). Phenotype stability of soybean genotypes for characters related to the physiological quality of seeds produced under different environmentall conditions. Australian Journal of Basic and Applied Sciences, 10(15), 279-289.

Szareski, V. J., Carvalho, I. R., Nardino, M., Pelegrin, A. J., Ferrari, M., Gaviraghi, R., ... Souza, V. Q. (2016). Competition of soybean genotypes cultivated in lowlands of Rio Grande doSul, Brazil. International Journal of Current Research, 8, 39714-39718.

Tchanz, A. T. (1982). Soybean rust epidemiology: Final report. Shanhau, Taiwan: Asian Vegetable Research and Development Center.

Teló, G. M., Marchesan, E., Menezes, N. L. de, Ferreira, R. B., Sartori, G. M. S., Formentini, T. C., \& Hansel, D. S. S. (2012). Aplicação de fungicida em cultivares de arroz irrigado e seu efeito na qualidade de sementes. Revista Brasileira de Sementes, 34(1), 099-107. https://doi.org/10.1590/S0101-31222012000100013

Vargas, R. L., Schuch, L. O. B., Barros, W. S., Rigo, G. A., Szareski, V. J., Carvalho, I. R., ... Pedo, T. (2018). Macronutrients and Micronutrients Variability in Soybean Seeds. Journal of Agricultural Science, 10, 209-222. https://doi.org/10.5539/jas.v10n4p209

Yang, X. B., Tschanza, T., Dowlerw, M., \& Wang, T. C. (1991). Development of yield loss models in relation to reductions of components of soybeans infected with Phakopsora pachyrhizi. Phytopathology, 81, 1420-1426. https://doi.org/10.1094/Phyto-81-1420 
Yorinori, J. T., \& Lazzarotto, J. J. (2004). Situação da ferrugem asiática da soja no Brasil e na América do Sul (Documentos, Embrapa Soja, 236, p. 27). Londrina: Embrapa Soja.

\section{Copyrights}

Copyright for this article is retained by the author (s), with first publication rights granted to the journal.

This is an open-access article distributed under the terms and conditions of the Creative Commons Attribution license (http://creativecommons.org/licenses/by/4.0/). 